\title{
Pengaruh Strategi Pembelajaran (Kooperatif Model STAD dan Konvensional) terhadap Perolehan Belajar IPA Fisika Siswa Kelas IX yang Memiliki Tingkat Perkembangan Kognitif yang Berbeda
}

\author{
Marungkil Pasaribu ${ }^{1}$ \\ 1Teknologi Pembelajaran-Universitas Negeri Malang
}

\begin{tabular}{l}
\hline INFO ARTIKEL \\
\hline Riwayat Artikel: \\
Diterima: Tgl-Bln-Thn \\
Disetujui: Tgl-Bln-Thn
\end{tabular}

\section{Kata kunci:}

Kelompok belajar

Kuasi eksperimen

Rancangan faktorial

Analisis data

\begin{abstract}
ABSTRAK
Abstract: The purpose of the studies are to examine significance of the difference in learning outcomes between students group treats by implementation of cooperative learning strategies and conventional learning strategies learning in science physics. In order to obtain the above purpose, quasi experiment was applied to students. The factorial $2 \times 4$ with nonequivalent control group design was employed to test mean scores. Based on the data analysis, the findings there was a significant difference on students learning outcome in physics between the class treated by cooperative learning strategies STAD and conventional strategies.

Abstrak: Penelitian ini bertujuan untuk menguji signifikansi perbedaan hasil belajar IPA Fisika antara kelompok belajar yang diberi perlakuan dengan strategi pembelajaran kooperatif model STAD dan strategi pembelajaran konvensional. Untuk mencapai tujuan tersebut, dilakukan penelitian kuasi eksperimen pada siswa. Eksperimen menggunakan rancangan factorial $2 \times 4$ dengan versi disain faktorial non equivalen control group. Berdasarkan analisis data ditemukan ada perbedaan yang signifikan pada perolehan belajar IPA fisika antara kelas yang diberi perlakuan dengan strategi pembelajaran kooperatif dengan model STAD dan kelas yang diberi perlakuan dengan strategi pembelajaran konvensional.
\end{abstract}

\author{
Alamat Korespondensi: \\ Marungkil Pasaribu \\ Teknologi Pembelajaran \\ Pascasarjana Universitas Negeri Malang \\ Jalan Semarang No. 5 Malang 65154 \\ E-mail: marungkil.psrbu@gmail.com
}

Telah banyak ditemukan bahwa proses dan produk pembelajaran IPA fisika di sekolah menengah dan bahkan di perguruan tinggi baik di Indonesia maupun di luar negeri belum optimal (Berg, 1991; Gardner, 2011; Masjkur, 1996; Nachtigall, 1998). Penelitian juga menunjukkan bahwa banyak lulusan sekolah menengah belum memiliki kompetensi seperti yang diharapkan, dan bahkan banyak diantara mereka seolah-olah belum pernah belajar fisika. Dipihak lain, (Bent, 1984) menemukan bahwa banyak siswa sekolah menengah dan mahasiswa tingkat perkembangan kognitifnya masih berada pada tahap operasi kongkrit. Temuan-temuan ini mengindikasikan bahwa pemahaman siswa terhadap materi pelajaran IPA fisika berkategori rendah. Akibatnya, proses dan produk pengajaran fisika sampai saat ini tetap menjadi sorotan baik oleh para praktisi maupun oleh para teoritisi pendidikan.

Rendahnya proses dan produk pembelajaran fisika tak dapat dipungkiri berakibat kepada rendahnya pemahaman siswa terhadap isi materi pelajaran. Penelitian dalam beberapa tahun ini menyimpulkan bahwa rendahnya pemahaman siswa terhadap materi pelajaran IPA merupakan sumber kesulitan utama dalam menghubungkan dan mengembangkan konsep yang saling berkaitan (Berg, 1991). Dalam proses belajarnya, siswa lebih cenderung dibelajarkan dengan pemberian informasi dari pada memahami materi pelajaran yang dipelajari, sehingga mereka tidak dapat mengembangkan konsep dengan baik. (Pearsall, Skipper, \& Mintzes, 
1997) menemukan bahwa siswa sering gagal dalam memahami konsep dalam mata pelajaran IPA. Jika siswa tidak dapat memecahkan suatu permasalahan dalam mata pelajaran IPA maka langkah yang pertama dilakukan oleh guru adalah memeriksa pemahaman siswa tersebut terhadap konsep yang terdapat dalam permasalahan.

(Gardner, 2011) menyatakan setidaknya ada tiga faktor yang secara umum dapat menghalangi pemahaman siswa, yaitu: (1) pemilihan metode pembelajaran yang cenderung mentoleransi pemahaman yang seragam, (2) substansi kurikulum yang cenderung dekontekstual dan (3) perumusan tujuan yang jarang diorientasikan pada pencapaian pemahaman secara mendalam. Kesalahan yang bersifat teknis dan substansial ini disamping menghambat pemahaman juga berpeluang menimbulkan miskonsepsi pada siswa. Ketiga faktor di atas sering terlihat pada bentuk pembelajaran yang berpusat pada guru.

Pembelajaran yang berpusat pada guru sudah saatnya digeser menuju pada pembelajaran yang berpusat pada asumsi bahwa pengetahuan dibangun oleh siswa sendiri (Howe \& Jones, 1993). Iklim kelas yang ditemukan dalam praktek-praktek pembelajaran yang berpusat pada guru cenderung bernuansa kompetitif yang memberikan peluang berlakunya hukum rimba dan sangat merugikan siswa yang kemampuan akademiknya rendah (Cooper, 1990; Johnson, Johnson, \& Smith, 1998; Joyce, Marsha, \& Emily, 2009; Marzano, Gaddy, \& Dean, 2000). Suasana kompetitif senantiasa menjadi siksaan psikologis bagi siswa yang kurang mampu (Slavin, 2006).

Pembelajaran kooperatif merupakan salah satu pembelajaran yang berpusat pada siswa. Pembelajaran kooperatif sangat cocok untuk mengembangkan kegiatan yang berdasarkan inkuiri, memfasilitasi dan membimbing pembelajaran, mendisain dan mengatur lingkungan pembelajaran dan mendukung tekhnik rekonstruksi kognitif (Pratt, 2003). Tekhnik ini menelusuri interaksi antara pengetahuan awal, motivasi belajar, interaksi sosial dan pesan pembelajaran. Pembelajaran kooperatif yang didasari oleh paradigma pembelajaran pemodelanan akan menyediakan dukungan pada proses rekonstruksi pemahaman melalui interaksi sosial. Salah satu tujuan pembelajaran kooperatif adalah meningkatkan prestasi akademik siswa (Hill \& Hill, 1993; Johnson \& Johnson, 1981, 1987)(Hill \& Hill, 1993; Johnson \& Johnson, 1987; Johnson, et al., 1981). Dengan berkolaborasi, siswa terlibat secara bersama dalam mengolah informasi. Pembelajaran kolaboratif memberikan kontribusi terhadap peningkatan ketrampilan berpikir dan pemahaman yang lebih mendalam (Hill \& Hill, 1993). Jika siswa sudah memiliki ketrampilan kooperatif tingkat mahir, mereka akan memiliki ketrampilan mengelaborasi suatu konsep yang akan menghasilkan suatu pemahaman lebih dalam dan hasil belajar yang lebih tinggi yang pada akhirnya akan menumbuhkan motivasi yang positif dan sikap yang lebih baik.

Salah satu tekhnik pembelajaran kooperatif adalah Student Teams Achievement Division selanjutnya di singkat STAD. Siswa dalam suatu kelas tertentu dipecah jadi kelompok dengan anggota 4-5 orang, tiap kelompok harus heterogen, terdiri dari laki-laki dan perempuan, berasal dari berbagai suku, memiliki kemampuan tinggi, sedang, dan rendah. Saat belajar berkelompok, siswa saling membantu untuk menuntaskan materi yang dipelajari. Penerapan metode ini menggunakan beberapa pendekatan pembelajaran, seperti pendekatan kooperatif, kontekstual, dan konstruktif. Keterpaduan ini dapat terwujud dalam proses perencanaan, pelaksanaan, dan hasil nilai atau kemampuan anak pada suatu kegiatan belajar mengajar yang konsisten.

IPA fisika memerlukan pemecahan masalah yang memiliki karakteristik khusus dan ketrampilanketrampilan interpretasi konsep yang ternyata sering menyulitkan pekerjaan secara individual. Zhaoyao (2002) menyatakan bahwa belajar fisika bukanlah sebatas mengingat fakta, melainkan berkenaan dengan pemahaman dengan karakteristik matematika. Pelajaran semacam ini secara tidak langsung menggiring guru untuk kreatif dan antisipatif terhadap keefektifan pembelajaran di sekolah. Belajar fisika melibatkan kemampuan dan ketrampilan interpretasi fisis, transformasi besaran dan satuan, logika matematis, dan kemampuan numerasi yang akurat. Pemahaman konsep dalam fisika bukanlah diperoleh hanya pada penghapalan semata, tetapi pebelajar haruslah diperhadapkan kepada situasi yang menuntut dirinya sendiri untuk mencari dengan menginvestigasi secara langsung. Mereka harus dapat menghubungakan konsepkonsep yang saling berkaitan untuk dapat mengembangkan pemahaman mereka (Thompson, McLaughlin, \& Smith, 1995).

Pengajaran di kelas akan sangat bermanfaat apabila isi kurikulum disesuaikan dengan perkembangan kognitif anak (Piaget, 1975). Menurut teori perkembangan kognitif Piaget, siswa SMP sebagian telah berada berada dalam tingkat operasi formal dan konkrit dan sebagian lagi masih berada dalam tahap transisi dari 
fase konkrit ke fase operasi formal. Dalam tahap ini, mereka diharapkan sudah mulai mampu berpikir secara abstrak. Oleh karena itu, pembelajaran IPA di SMP hendaknya sudah mengenalkan siswa kepada kemampuan untuk mulai melakukan investigasi yang sifatnya sederhana. Mereka sudah dapat dilatih untuk melakukan pengamatan, mengidentifikasi variabel, merumuskan hipotesis yang berdasarkan pustaka, dan mampu melaporkan hasil percobaan secara lisan maupun tulisan. Dalam mewujudkan situasi seperti ini, tekhnik pembelajaran kooperatif sebagai rancangan pembelajaran yang bernuansa kolaboratif (Jacob, 1999; Slavin, 2006) sangat diperlukan dalam tekhnik pelajaran IPA.

Berdasarkan latar belakang masalah yang telah diuraikan, maka maka dalam penelitian ini dirumuskan permasalahan sebagai berikut (1) apakah terdapat perbedaan hasil belajar IPA fisika yang signifikan antara kelompok pebelajar yang diberi perlakuan dengan strategi pembelajaran kooperatif tekhnik STAD dan strategi pembelajaran konvensional? (2). apakah terdapat perbedaan hasil belajar IPA fisika yang signifikan antara masing-masing kelompok tingkat perkembangan kognitif ? dan (3) apakah terdapat pengaruh interaksi yang signifikan antara strategi pembelajaran dengan tingkat perkembangan kognitif pebelajar terhadap hasil belajar IPA fisika?.

\section{METODE}

Penelitian ini hendak menyelidiki dan mendapatkan bukti-bukti yang menyatakan pengaruh strategi pembelajaran dalam proses membelajarkan terhadap hasil belajar pebelajar yang memiliki tingkat perkembangan kognitif konkrit, transisi, awal formal dan tahap operasi formal. Untuk menguji keampuhan strategi pembelajaran yang diselidiki, digunakan rancangan penelitian eksperimen semu dengan menggunakan teknik pengukuran prates-posttes control group design versi factorial $2 \times 4$ (Tuckman, 1999). Jadi, prosedur eksperimen terdiri atas pra-tes, perlakuan dan pasca-tes. Penyelidikan dilakukan secara serempak terhadap kelompok strategi pembelajaran kooperatif tekhnik STAD dan kelompok strategil pembelajaran konvensional.

Subjek penelitian ini adalah pebelajar kelas IX SMP N se kota Malang. Penetapan subjek penelitian dilakukan sebanyak dua tahap, yaitu: (1) menetapkan sekolah yang mana pebelajar dari sekolah tersebut akan dijadikan sebagai subjek kelompok eksperimen dan kontrol, dan (2) menetapkan kelas yang mana seluruh pebelajar yang ada dalam kelas tersebut akan mendapat perlakuan. Tiga sekolah yang terpilih secara random untuk mewakili seluruh populasi SMP N yang tersebar dikota Malang adalah SMP N 3, SMP N 5 dan SMP N 18 Malang tahun ajaran 2009/2010. Dari masing-masing sekolah selanjutnya dipilih secara acak 2 kelas untuk dijadikan sebagai kelas kontrol dan eksperimen. Jumlah pebelajar yang mengikuti pembelajaran dengan strategi pembelajaran kooperatif adalah 108 orang dan yang mengikuti pembelajaran dengan strategi konvensional adalah 111 orang. Rentangan usia subjek penelitian terletak antara 14 hingga 15 tahun.

Bahan perlakuan dan instrument yang digunakan dalam penelitian ini berupa: bahan ajar yang disesuaikan dengan isi kurikulum KTSP standart isi 2006, panduan pebelajar dan panduan guru untuk masing-masing strategi pembelajaran, instrument untuk mengukur pengetahuan awal (pratest) dan setelah diberikan perlakuan (posttest) dan instrument untuk mengukur tingkat perkembangan kognitif pebelajar. Instrumen pra-test yang digunakan untuk mengukur kemampuan awal pebelajar mencakup konsep Listrik Dinamis, Sumber Arus Listrik dan Energi dan Daya Listrik. Instrumen post test yang digunakan untuk mengukur variabel tergantung sebagai akibat langsung dari perlakuan adalah mencakup materi belajar pada konsep Listrik Dinamis, Sumber Arus Listrik dan Energi dan Daya Listrik. Sebelum tes diujikan kepada pebelajar terlebih dahulu diujicobakan untuk mengetahui konstruksi dan kelayakan tiap butir tes.

Untuk mengukur tingkat perkembangan kognitif pebelajar digunakan tes kemampuan penalaran formal (TKPF). TKPF yang digunakan dalam penelitian ini adalah yang diadaptasi dalam tekhnik Indonesia oleh Nur tahun 1991. Pengadaptasian ke dalam bahasa Indonesia dilakukan dengan cara menterjemahkan bahasa dan menyesuaikan isi test dengan kondisi pebelajar Indonesia. TKPF ini terdiri dari 10 item test. Dua item test dipilih untuk mengukur tiap-tiap operasi dari lima penalaran formal, yaitu pengontrolan variabel, penalaran proporsional, penalaran probabilistrik, penalaran korelasidan penalaran kombinatorial.

Hasil belajar dalam penelitian ini dianalisis dengan menggunakan teknik analisis deskriptif dan analisis kovarians atau analisis varians dua jalur. Analisis deskriptif digunakan untuk mendeskripsikan nilai serta rerata dan simpangan baku variabel hasil belajar. Analisis varians dua jalur digunakan untuk menguji hipotesisi penelitian. Pengujian hipotesis nol dilakukan pada taraf signifikansi $5 \%(0,05)$ dengan bantuan prosedur Two Way Anova pada program SPSS versi 17,0 for windows. 


\section{HASIL}

Hasil pengukuran terhadap hasil belajar kelas kontrol dan kelas eksperimen ditunjukkan pada Tabel 1 Terlihat bahwa rerata hasil oleh kelas kontrol yang berjumlah 105 subjek belajar adalah 34,133 dengan simpangan baku 4,24. Ketuntasan belajar yang diperoleh oleh kelas kontrol yang diberi perlakuan dengan strategi konvensional adalah $76 \%$. dan berkategori cukup. Rerata hasil belajar oleh kelas eksperimen $(\mathrm{N}=$ 102) yang mendapat perlakuan dengan strategi kooperatif adalah sebesar 36,525 dengan simpangan baku 3,74 . Ketuntasan belajar oleh kelas ini adalah $81 \%$ dan berada pada kategori baik. Tingkat penguasaan seluruh pebelajar adalah $78 \%$, dengan skor maksimum adalah 44 dan skor minimum adalah 26 untuk kelas kontrol dan 27 untuk kelas eksperimen.

Tabel1. Deskripsi Hasil Belajar Kelas Kontrol dan Eksperimen

\begin{tabular}{cccccc}
\hline Kelas & N & Mean & Std. Deviation & Minimum & Maximum \\
\hline Kontrol & 105 & 34.133 & 4.2373 & 26.0 & 44.0 \\
Eksperimen & 102 & 36.525 & 3.7399 & 27.0 & 44.0 \\
Total & 207 & 35.312 & 4.0515 & 26.0 & 44.0 \\
\hline
\end{tabular}

Deskripsi hasil belajar menurut variabel moderator, tingkat perkembangan kognitif ditunjukkan pada Tabel 2. Dari tabel terlihat kkor rerata hasil belajar pada masing-masing tingkat perkembangan kognitif oleh kelas eksperimen lebih tinggi bila dibandingkan dengan keompok kontrol. Skor rerata hasil belajar pada tingkat perkembangan kognitif formal baik yang mendapat perlakuan strategi pembelajaran kooperatif maupun strategi pembelajaran konvensional telah berkategori baik sekali. Masing-masing kelompok telah mencapai penguasaan $89 \%$ dan $87 \%$. Rerata hasil belajar pada kelompok tingkat perkembangan kognitif awal formal pada kelompok eksperimen dan kontrol telah berkategori baik dengan pencapaian masing-masing $83 \%$ dan $80 \%$. Demikian juga pada kelompok tingkat perkembangan kognitif transisi, kelas yang diberi perlakuan dengan strategi pembelajaran kooperatif telah berada pada kategori baik dengan pencapaian $80 \%$ dan dengan strategi pembelajaran konvensional berada pada kategori cukup dengan pencapaian $74 \%$. Akan tetapi, kelompok pebelajar yang berada pada tingkat perkembangan kognitif kongkrit kelas eksperimen masih berada pada kategori sedang dan kelas kontrol yang mendapat perlakuan strategi pembelajaran konvensional tingkat penguasaannya hanya sebesar $68 \%$, atau masih berada pada kategori kurang.

Tabel 2. Deskripsi Hasil Belajar Kelas Kontrol dan Eksperimen Berdasarkan Tingkat Perkembangan Kognitif

\begin{tabular}{ccccccc}
\hline Kelas & & N & Mean & Std. Dev & Min & Max \\
\hline Kontrol & Kongkrit & 29 & 30.655 & 1.9091 & 27.0 & 34.0 \\
& Transisi & 34 & 33.353 & 1.8689 & 30.0 & 37.0 \\
& Awal Formal & 26 & 36.000 & 2.1166 & 33.0 & 40.0 \\
& Formal & 16 & 39.062 & 2.2648 & 36.0 & 43.0 \\
Eksperimen & Kongkrit & 29 & 34.155 & 2.9311 & 28.0 & 39.0 \\
& Transisi & 32 & 36.188 & 2.1767 & 32.0 & 40.0 \\
& Awal Formal & 24 & 37.458 & 1.9556 & 34.0 & 41.0 \\
& Formal & 17 & 39.882 & 1.8669 & 37.0 & 43.0 \\
& Total & 207 & 35.312 & 3.4579 & 27.0 & 43.0 \\
\hline
\end{tabular}

Tabel 3 menjelaskan 3 pengaruh terhadap hasil belajar yang diteliti, yakni pengaruh strategi pembelajaran, pengaruh tingkat perkembangan kognitif dan pengaruh interaksi antara strategi pembelajaran dan tingkat perkembangan kognitif bersama-sama terhadap hasil belajar. Pada Tabel 3 variabel strategi pembelajaran dengan dimensi kooperatif dan konvensional dinyatakan dengan identitas kelas menunjukkan bahwa besar angka signifikansi pada variabel ini adalah 0,000 . Karena besaran ini lebih kecil dari signifikansi penerimaan H0 0,05 maka hipotesis nol (H0) yang menyatakan "Hasil belajar IPA fisika kelompok pebelajar yang diberi perlakuan dengan strategi pembelajaran kooperatif tidak berbeda dengan yang diberi perlakuan dengan strategi pembelajaran konvensional" ditolak. Keputusan statistik ini memberikan peluang untuk menyatakan bahwa hasil belajar IPA fisika antara kelompok pebelajar yang mengikuti strategi pembelajaran kooperatif berbeda secara signifikan dengan kelompok pebelajar yang mengikuti strategi pembelajaran konvensional 
Tabel 3 Deskripsi Hasil Analisis Hasil Belajar Kelas Kontrol dan Eksperimen

Tests of Between-Subjects Effects Dependent Variable:Skor

\begin{tabular}{cccccc} 
Source & $\begin{array}{c}\text { Type III Sum } \\
\text { of Squares }\end{array}$ & df & Mean Square & F & Sig. \\
\hline Corrected Model & $1525.748^{\mathrm{a}}$ & 7 & 217.964 & 46.271 & .000 \\
Intercept & 248363.190 & 1 & 248363.19 & 52724.643 & .000 \\
Kelas & 224.053 & 1 & 224.053 & 47.564 & .000 \\
TktPerkKog & 1180.307 & 3 & 393.436 & 83.522 & .000 \\
Kelas * TktPerkKog & 52.251 & 3 & 17.417 & 3.697 & .013 \\
Error & 937.404 & 199 & 4.711 & & \\
Total & 260573.250 & 207 & & & \\
Corrected Total & 2463.152 & 206 & & & \\
\hline
\end{tabular}

Tabel 3 juga memperlihatkan bahwa variabel tingkat perkembangan kognitif memberikan nilai $P$-value sebesar 0,000. Karena nilai $P$-value ini lebih kecil dari 0,05 maka hipotesis statistik (H0) yang menyatakan "Hasil belajar IPA fisika antara masing-masing kelompok pebelajar pada tingkat perkembangan kognitif adalah tidak berbeda" ditolak. Artinya hasil belajar masing-masing tingkat perkembangan kognitif berbeda secara signifikan. Hasil ini didukung oleh hasil analisis dengan menggunakan pendekatan Two Way Anove dengan Post Multiple Comparison Tukey diperoleh hasil pengujian seperti ditunjukkan pada Tabel 4.

Tabel 4 Hasil Pengujian Rerata Hasil Belajar Berdasarkan Tingkat Perkembangan Kognitif

\begin{tabular}{cccccc} 
TktPerKog & $\mathbf{N}$ & \multicolumn{4}{c}{ Subset for alpha $=\mathbf{0 . 0 5}$} \\
& & $\mathbf{1}$ & $\mathbf{2}$ & $\mathbf{3}$ & $\mathbf{4}$ \\
\hline Kongkrit & 58 & 32.405 & & & \\
Transisi & 66 & & 34.727 & & \\
Awal Formal & 50 & & & 36.700 & \\
Formal & 33 & & & & 39.485 \\
Sig. & & 1.000 & 1.000 & 1.000 & 1.000 \\
\hline
\end{tabular}

Tabel Tests of Between-Subjects Effects, faktor strategi pembelajaran dan tingkat perkembangan kognitif memberikan nilai $P$-value diperoleh sebesar 0,013. Karena harga $P$-value lebih kecil dari 0,05 maka hipotesis statistik H0 ditolak. Keputusan statistik ini memberi peluang untuk menyatakan bahwa hipotesis yang berbunyi "Tidak ada pengaruh interaksi antara strategi pembelajaran dengan tingkat perkembangan kognitif terhadap hasil belajar IPA fisika" ditolak. Artinya strategi pembelajaran tidak memberikan pengaruh yang sama terhadap masing-masing tingkat perkembangan kognitif kongkrit, transisi, awal formal dan formal. Dengan menggunakan pendekatan Two Way Anove dengan Post Multiple Comparison Tukey diperoleh hasil pengujian seperti ditunjukkan pada Tabel 5. Output pengujian menghasilkan 6 subsets for $a=0,05$ yang menyatakan bahwa ada 6 jenis kelompok yang memiliki rerata yang sama.

Tabel 5 Hasil Pengujian Rerata Tingkat Perkembangan Kognitif Kelas Kontrol dan Eksperimen

\begin{tabular}{cccccccc}
\hline TktKog & $\mathbf{N}$ & $\mathbf{6}$ & $\mathbf{2}$ & $\mathbf{3}$ & $\mathbf{4}$ & $\mathbf{5}$ & $\mathbf{6}$ \\
& & $\mathbf{1}$ & $\mathbf{2}$ & & \\
KongK & 29 & 30.655 & & & & & \\
TranK & 34 & & 33.353 & & & & \\
KongE & 29 & & 34.155 & 34.155 & & & \\
AwForK & 26 & & & 36.000 & 36.000 & & \\
TranE & 32 & & & & 36.187 & & \\
AwForE & 24 & & & & 37.458 & 37.458 & \\
ForK & 16 & & & & & 39.062 & 39.062 \\
ForE & 17 & & & & & & 39.882 \\
Sig. & & 1.000 & .904 & .068 & .280 & .174 & .893 \\
\hline
\end{tabular}

Pengaruh interaksi antara strategi pembelajaran yang diberikan sebagai perlakuan dan tingkat perkembangan kognitif lebih jelas terlihat dari grafik estimated marginal rerata skor hasil belajar dengan 
perkembangan tingkat kogntif (Gbr. 1). Grafik antara estimated marginal means skor hasil belajar dengan tingkat perkembangan kognitif pebelajar menunjukkan bahwa pengaruh perlakuan strategi pembelajaran tidaklah sama dan tidak konstan. Hal ini terlihat dari kedua garis, hasil belajar dengan perlakuan strategi pembelajaran kooperatif dan strategi pembelajaran konvensional tidak paralel. Perbedaan kedua garis untuk perkembangan kognitif kongrit terlihat lebih besar, tetapi selanjutnya berkurang pada tingkat perkembangan kognitif transisi, dan bahkan perbedaan semakin kecil pada tingkat perkembangan kognitif awal formal dan formal. Jadi strategi pembelajaran kooperatif memberikan hasil yang lebih baik dibandingkan dengan strategi pembelajaran konvensional hanya pada tingkat perkembangan kognitif kongkrit dan transisi.

Estimated Marginal Means of Skor

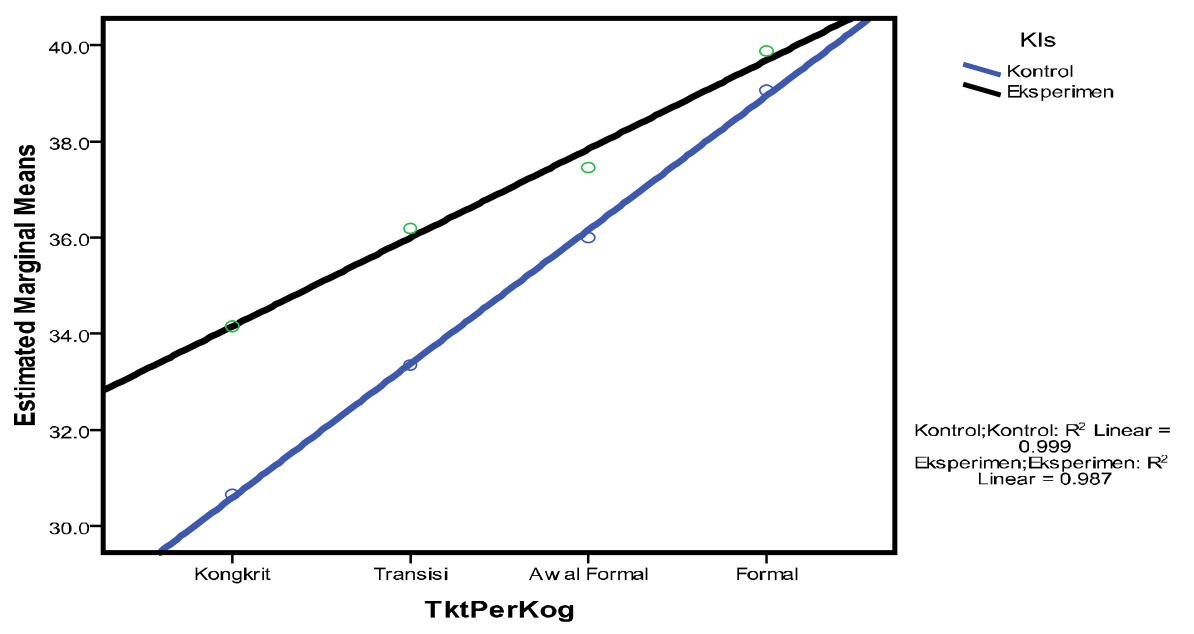

Gambar 1. Grafik Interaksi antara Strategi Pembelajaran Tingkat Perkembangan Kogntif.

\section{PEMBAHASAN}

Rerata hasil belajar kelas kontrol sebelum diberikan perlakuan adalah sebesar 18,15 dari skor maksimum 45 dengan standar deviasi 2,76. Pencapaian belajar oleh kelompok ini adalah sekitar $40 \%$. Rerata hasil belajar kelas eksperimen adalah 18,12 dengan standart deviasi 2,74. Pencapaian belajar oleh kelompok ini juga sekitar 40\%. Setelah kepada kedua kelas diberikan perlakuan yang berbeda, kelas kontrol memperoleh rerata hasil belajar sebesar 34,133 dengan standard beviasi 4,24 dan kelas eksperimen dengan rerata skor 36,525 dengan standart deviasi 3,74. Pencapaian oleh kelas kontrol naik menjadi $76 \%$ sedangkan kelas eksperimen memperoleh kenaikan yang lebih besar lagi, yakni menjadi $81 \%$. Dari segi pengkategorian dalam pencapaian hasil belajar, kelas kontrol mengalami kenaikan dari kategori kurang menjadi kategori sedang sesudah perlakuan diberikan. Akan tetapi berbeda halnya dengan kelas eksperimen, kelas ini memperoleh perubahan kategori dari kategori kurang menjadi kategori baik setelah perlakuan.

Dari hasil analisis pengujian data hasil belajar yang menggunakan pendekatan Two Way Anove, diperoleh kesimpulan bahwa hasil belajar kelas kontrol dan eksperimen berbeda secara signifikan. Skor rerata hasil belajar kelas eksperimen yang diberi perlakuan dengan strategi pembelajaran kooperatif menunjukkan hasil yang lebih tinggi dibandingkan dengan kelas kontrol yang diberi perlakuan dengan strategi pembelajaran konvensional. Strategi pembelajaran yang berbeda menyebapkan terjadinya perbedaan hasil belajar, walaupun diberi bahan pembelajaran, perangkat pembelajaran, waktu proses belajar pembelajaran yang sama, soal-soal tes dan pembelajar yang sama. Hasil pembelajaran yang berbeda ini diduga disebabkan adanya perbedaan perlakuan yang diberikan terhadap pebelajar, yakni perlakuan berupa penerapan strategi pembelajaran. Temuan ini menunjukkan bahwa penggunaan strategi pembelajaran kooperatif dalam pembelajaran memberikan hasil belajar yang lebih tinggi dibanding dengan strategi pembelajaran konvensional.

Ada dua alasan peryebab strategi pembelajaran kooperatif memberikan hasil belajar yang lebih baik dari strategi pembelajaran konvensional/ pembelajaran individual, yakni adanya tujuan bersama dan tanggung 
jawab individu (Slavin, 2006). Adanya tujuan bersama memotivasi pebelajar untuk membantu anggota kelompoknya untuk belajar. Mereka membangun sikap saling ketergantungan secara positif antara individuindividu dalam kelompok, serta memberikan penjelasan mengapa mereka bekerjasama. Dengan adanya dukungan antar pebelajar maka pebelajar menjadi lebih memfokuskan diri untuk lebih produktif dalam melibatkan dirinya dalam menyelesaikan tugasnya yang merujuk kepada peningkatkan rasa percaya diri dan kemampuan untuk mengatasi kesulitan. Keterlibatan yang tinggi dari masing-masing anggota kelompok dalam strategi pembelajaran kooperatif mengarah pada suatu proses belajar yang solid yang bukan terlihat hanya pada permukaan saja (Entwistle \& Tait, 1993). Tanggung jawab individu, sebagai pengukur keaktifan pembelajaran, akan membangun kondisi untuk terlibat secara aktif dalam menyelesaikan tugas kelompok (Panitz, 1999).

Hal ini sejalan dengan temuan (Schneider \& Csikszentmihalyi, 2000) yang menyatakan bahwa dalam strategi pembelajaran kooperatif pebelajar lebih banyak mengkonsentrasikan waktunya dengan kegiatan yang berkaitan dengan tugas akademik yang sedang mereka hadapi dibanding dengan pengajaran konvensional. Hasil penelitian (Csikszentmihalyi \& Larson, 2014) menyimpulkan walaupun sangat sulit untuk berkonsentrasi dalam pembelajaran kooperatif, namun pebelajar merasa lebih terkonsentrasi saat terlibat aktif dibanding dengan saat mengikuti proses pembelajaran dengan pembelajaran konvensional.

Bagi pebelajar yang diberi perlakuan dengan strategi pembelajaran konvensional, pada awal pembelajarannya mereka telah melakukan penyesuaian pengetahuan yakni berupa konsep-konsep sesuai dengan pokok bahasan yang mereka hadapi. Pebelajar diajar secara formal untuk memahami konsep-konsep. Apabila timbul keraguan maka mereka bertanya pada guru, padahal konsep-konsep dalam IPA dirumuskan dan idefenisikan oleh para pakar dalam IPA. Strategi pembelajaran ini tidak memfasilitasi pebelajar untuk belajar dengan melakukan kegiatan ilmiah. Mereka kurang mendapatkan pengalaman untuk memahami konsep secara kongkrit, sehingga mereka tidak dapat melakukan akomodasi terhadap konsep-konsep yang bersifat kongkrit. Pebelajar kurang dilibatkan dalam proses pembelajaran. Efek langsung dari kondisi pembelajaran ini adalah pebelajar dipaksa untuk membangun pengetahuan dengan menghafalkan konsepkonsep tersebut. Strategi pembelajaran ini cenderung tidak produktif dan membosankan. Menurut (Ratnawati, 2016), mengingat, dan menghafal tidak dianggap sebagai belajar yang sesungguhnya karena kegiatan tersebut tidak memasukkan proses assimilasi dan pemahaman.

Berdasarkan hasil tes kemampuan penalaran formal (TKPF), diketahui bahwa seluruh pebelajar kelas IX SMP di kota Malang berusia pada rentang 14 hingga 16 tahun, akan tetapi tingkat perkembangan kognitif mereka belum seluruhnya berada pada tahap operasi formal. Pada rentang usia ini seharusnya tingkat penalaran mereka telah berada pada tahap operasi formal (Piaget, 1975) pebelajar yang telah berusia di atas 11 tahun seharusnya telah berada pada tahap berfikir operasi formal. Akan tetapi, dari 207 pebelajar yang digunakan sebagai subjek dalam penelitian masih ditemukan sebanyak $28 \%$ pebelajar yang tingkat perkembangan kognitifnya berada pada operasi kongkrit, (32\%) berada pada operasi transisi, operasi awal formal $24 \%$ dan hanya $16 \%$ saja yang telah berada pada tahap perkembangan kognitif formal. Hasil penelitian ini mendukung hasil penelitian yang dilakukan oleh (Ardhana, 1983; Nurrenbern, 2001; Scerri, 2003). Bahkan (Bent, 1984) menyatakan masih banyak mahasiswa yang tingkat perkembangan kognitifnya berada pada operasi kongkrit.

Ada beberapa faktor penyebab terjadinya perbedaan tingkat perkembangan kognitif pada usia yang berada pada rentangan 14 hingga 16 ini, yakni perkembangan organic dan kematangan (maturation) sistim saraf, latihan dan pengalaman fisik (physical experience), interaksi sosial dan transmisi (social transmission), dan ekuilibrasi dan mekanismenya (equilibration) (Suparno, 2001; Woolfolk, 2007). Kematangan berkaitan dengan sistim syaraf dan mempunyai peranan penting dalam perkembangan awal kognitif. Latihan berfikir, merumuskan masalah dan memecahkannya, serta mengambil kesimpulan akan membantu seseorang untuk mengembangkan inteligensinya. Melalui pengalaman fisik akan terbentuk pengetahuan fisik dalam diri individu, karena pengetahuan fisik merupakan pengetahuan tentang benda-benda yang ada diluar dan dapat diamati dalam kenyataan eksternal (Carin \& Sund, 1975). Melalui pengalaman logika matematika individu akan membangun hubungan-hubungan atau abstraksi yang didapat dari hasil interaksi terhadap objek. Melalui transmisi sosial akan terbentuk pengetahuan sosial dalam diri individu. Ia akan tertantang untuk mengembangkan pemikiran dan pengetahuannya sendiri saat dia membandingkan pengetahuannya dengan pengetahuan teman sekelompoknya. Melalui ekuilibrasi individu akan mengintegrasikan foktor-faktor kematangan, pengalaman fisik, pengalaman logika matematika dan transmisi sosial. Proses ekuilibrasi 
terjadi melalui assimilasi dan akomodasi dan membuat individu memperoleh pengalaman baru. Equilibrasi membuat seseorang dapat menyatukan pengalaman luar dengan struktur mental atau kognitif (skemata).

Hasil pengujian hipotesis ke-3 menyimpulkan adanya pengaruh interaksi yang signifikan antara strategi pembelajaran dan tingkat perkembangan kognitif terhadap hasil belajar IPA Fisika pada materi ajar Listrik dinamis, sumber arus listrik dan energi dan daya listrik. Pada penelitian ini juga terungkap bahwa rerata hasil belajar dari pebelajar yang memiliki tingkat perkembangan kognitif yang sama yang diberi perlakuan dengan strategi pembelajaran kooperatif lebih tinggi dari yang diberi perlakuan dengan strategi pembelajaran konvensional. Dari temuan ini terlihat bahwa hasil belajar dengan strategi pembelajaran kooperatif STAD secara umum lebih baik dibandingkan dengan hasil belajar oleh strategi pembelajaran konvensional. Akan tetapi besar perubahan pada hasil belajar oleh masing-masing tingkat perkembangan kognitif tidaklah konstan. Perubahan pada hasil belajar pada kelas yang diberi perlakuan dengan strategi pembelajaran kooperatif STAD terlihat paling besar terjadi pada kelompok pebelajar pada tingkat perkembangan kognitif kongkrit dan transisi, sedangkan pada kelas yang diberi perlakuan dengan strategi pembelajaran konvensional terjadi pada kelompok tingkat perkembangan kognitif formal.

Terjadinya perbedaan hasil belajar karena adanya interaksi antara tingkat perkembangan kognitif pada tahap kongkrit dan transisi ini dengan strategi pembelajaran dapat dijelaskan sebagai berikut. Pertama, penerapan strategi pembelajaran kooperatif pada kedua tahap ini memfasilitasi pebelajar untuk belajar melalui pengamatan objek konkret, yang akan membantu pebelajar untuk membangun pengetahuan yang konkrit. Berdasarkan objek konkret pebelajar dibimbing untuk membuat hubungan antara hasil pengamatan dengan pengetahuan yang telah ada dalam struktur kognitif mereka, sehingga akhirnya pebelajar dapat membangun pengetahuan IPA fisika yang abstrak.

Secara teori, pemikiran pebelajar yang berada pada tahap perkembangan kongkrit sudah berdasarkan logika tertentu dengan sifat reversibilitas dan kekekalan. Mereka sudah dapat berfikir lebih menyeluruh dengan melihat banyak unsur dalam waktu yang sama. Pemikiran mereka dalam banyak hal sudah lebih teratur dan terarah karena sudah dapat berfikir seriasi, klasifikasi dengan lebih baik, bahkan mengambil kesimpulan secara probabilitas. Meskipun demikian pemikiran yang logis dengan segala unsurnya di atas masih terbatas dan diterapkan pada kalimat yang kongkrit, pemikiran itu belum diterapkan pada kalimat verbal, hipotesis dan abstrak. Pebelajar kelompok ini akan mengembangkan skemata mereka secara assimilasi atau akomodasi sehingga mereka memperoleh pengalaman yang baru.

Kedua, strategi pembelajaran kooperatif STAD memberikan kesempatan kepada pebelajar untuk secara aktif membuat abstraksi. Usaha menjelaskan sesuatu kepada anggota kelompok yang membantunya untuk melihat sesuatu dengan lebih jelas dan bahkan melihat inkonsistensi pandangan mereka sendiri. Melalui diskusi dalam merumuskan dan memberikan kesimpulan terhadap hasil pengamatan, pebelajar kelompok ini terlihat sangat terlibat dalam menuangkan kembali gagasan yang telah mereka miliki, maupun dalam menanggapi serta mendengarkan gagasan dan ide dari teman sekelompoknya. Dalam menghubungkan hasil pengamatan kelompok dengan teori yang telah diungkapkan para saintis, kelompok pebelajar ini terlihat sangat serius dalam mendengarkan penjelasan dari rekan mereka yang telah memahami materi. Mereka dengan segera menyesuaikan konsepsi yang telah mereka miliki dengan hasil pengamatan dan hasil dari diskusi serta penjelasan dari teman sekelompoknya. Saat konsepsi yang telah mereka miliki sesuai dengan hasil pengamatan dan penjelasan saat berdiskusi, kelompok pebelajar ini terlihat merasakan suatu kepuasan, dan saat konsepsi mereka tidak sesaui akan dengan segera meminta penjelasan terhadap teman kelompok yang telah mengerti. Akan tetapi kelompok pebelajar yang diberi perlakuan dengan strategi pembelajaran konvensional. (Arends, 2012) menyatakan bahwa diskusi dapat meningkatkan kemampuan berfikir pebelajar dan membantu mereka mengkonstruksi.

Hasil penelitian ini mendukung peryataan (Dick \& Carey, 2009) yang menyatakan dalam perancangan pembelajaran perlu memperhatikan karakteristik pebelajar. Hal yang sama juga dinyatakan oleh (Bunce, 2001) bahwa proses pembelajaran perlu menekankan interaksi antara pebelajar dengan lingkungan karena efek proses pembelajaran terhadap hasil belajar dipengaruhi oleh kesesuaian strategi pembelajaran dengan karakteristik pebelajar. Senada dengan pernyataan ini (Lyle \& Robinson, 2001) menyatakan kondisi mempengaruhi keefektipan dan efisiensi metode pembelajaran. Artinya keefektipan dan efisiensi penerapan strategi pembelajaran dipengaruhi oleh karakteristik pebelajar. Salah satu karakteristik pebelajar yang tidak dapat dimanipulasi adalah tingkat perkembangan kognitifnya. 


\section{SIMPULAN DAN SARAN}

\section{Simpulan}

Dari deskripsi umum hasil penelitian, pengujian hipotesis dan pembahasan hasil penelitian dapat disampaikan beberapa simpulan sebagai berikut: (1) Ada perbedaan yang signifikan pada perolehan belajar IPA fisika antara kelas yang diberi perlakuan dengan strategi pembelajaran kooperatif dengan model STAD dan kelas yang diberi perlakuan dengan strategi pembelajaran konvensional. Strategi pembelajaran kooperatif dengan setting STAD memberikan hasil belajar yang lebih baik dibandingkan dengan strategi pembelajaran konvensional. (2) Ada perbedaan yang signifikan pada perolehan belajar IPA fisika antara kelompok tingkat perkembangan kognitif yang berbeda. (3) Ada pengaruh interaksi antara strategi pembelajaran dengan tingkat perkembangan kognitif terhadap perolehan belajar sians fisika. Interaksi antara strategi pembelajaran dan tingkat perkembangan kognitif memiliki pengaruh yang berbeda terhadap hasil belajar IPA Fisika. Pengaruh keduanya lebih terlihat lebih besar pada perkembangan kognitif kongkrit dan transisi, dan semakin kecil pada kelompok tingkat perkembangan kognitif awal formal dan formal. Artinya, pebelajar yang masih berada pada tingkat perkembangan kognitif kongkrit dan transisi memperoleh manfaat yang lebih besar bila diaajar dengan menggunakan strategi pembelajaran kooperatif.

\section{Saran}

Berdasarkan simpulan yang telah dikemukakan, untuk mengkaji lebih lanjut hal-hal yang berpeluang yang menyebabkan terjadinya hasil penelitian seperti yang telah dikemukakan, maka disarankan dalam membelajarkan IPA Fisika pada konsep Listrik Dinamis, Sumber Arus Listrik dan Energi dan daya Listrik dengan menggunakan strategi pembelajaran kooperatif untuk lebih banyak menghadapkan siswa dalam menggali informasi dilaboratorium. Guru yang mengimplementasikan strategi pembelajaran kooperatif STAD hendaklah membimbing pebelajar dalam melakukan pengamatan terhadap objek secara langsung maupun dalam menghubungkan hasil pengamatan dengan teori yang diberikan oleh para saintis.

\section{DAFTAR RUJUKAN}

Ardhana, W. (1983). Kesanggupan Berpikir Formal ala Piaget dan Kemajuan Belajar di Sekolah. Disertasi Tidak Diterbitkan. Malang: Fakultas Pascasarjana IKIP Malang.

Arends, R. I. (2012). Learning to Teach Ninth Edition. New York: Mc Graw Hill Book Co.

Bent, H. A. (1984). Uses (and abuses) of models in teaching chemistry. Journal of Chemical Education, 61(9), 774.

Berg, E. V. D. (1991). Miskonsepsi fisika dan remediasi. Salatiga: Universitas Kristen Satya Wacana.

Bunce, D. M. (2001). Does Piaget still have anything to say to chemists? ACS Publications.

Carin, A. A., \& Sund, R. B. (1975). Teaching Science trough Discovery (3rd ed.). Ohio: C. E. Merrill Pub. Co.

Cooper, J. (1990). Cooperative learning and college teaching: Tips from the trenches. Teaching Professor, 4(5), 1-2.

Csikszentmihalyi, M., \& Larson, R. (2014). Validity and reliability of the experience-sampling method. In Flow and the foundations of positive psychology (pp. 35-54). Springer.

Dick, W., \& Carey, L. (2009). The Systematic Design of Instruction (7th ed.). Upper Saddle River, NJ \& Columbus, OH: Pearson.

Entwistle, N., \& Tait, H. (1993). Approaches to Studying and Preferences for Teaching in Higher Education: Implications for Student Ratings.

Gardner, H. (2011). The unschooled mind: How children think and how schools should teach. Basic Books (AZ).

Hill, S., \& Hill, T. (1993). The Cooperative Classroom (A guide to Cooperative Learning) Australia. Eleanor Curtain publishing.

Howe, A. C., \& Jones, L. (1993). Engaging children in science. Prentice Hall.

Jacob, E. (1999). Cooperative learning in context: An educational innovation in everyday classrooms. Suny Press.

Johnson, D. W., \& Johnson, R. T. (1981). Effects of cooperative and individualistic learning experiences on interethnic interaction. Journal of Educational Psychology, 73(3), 444.

Johnson, D. W., \& Johnson, R. T. (1987). Research shows the benefits of adult cooperation. Educational Leadership, 45(3), 27-30.

Johnson, D. W., Johnson, R. T., \& Smith, K. A. (1998). Cooperative learning returns to college what evidence is there that it works? Change: The Magazine of Higher Learning, 30(4), 26-35.

Joyce, B., Marsha, W., \& Emily, C. (2009). 8th edition Model of Teaching. Pearson Education, Inc.

Lyle, K. S., \& Robinson, W. R. (2001). Teaching science problem solving: An overview of experimental work. ACS Publications.

Marzano, R. J., Gaddy, B. B., \& Dean, C. (2000). What Works in Classroom Instruction. 
Masjkur, K. (1996). Penerapan strategi konflik kognitif untuk meluruskan salah konsep dalam belajar fisika. Proceedings Hasil Diseminasi Penelitian PMIPA. Jakarta: PPTA. Diten Dikti. Depdikbud.

Nachtigall, D. K. (1998). Preconceptions and misconceptions. Makalah.

Nurrenbern, S. C. (2001). Piaget's theory of intellectual development revisited. Journal of Chemical Education, 78(8), $1107-1111$.

Panitz, T. (1999). The motivational benefits of cooperative learning. New Directions for Teaching and Learning, 1999(78), 59-67.

Pearsall, N. R., Skipper, J. E. J., \& Mintzes, J. J. (1997). Knowledge restructuring in the life sciences: A longitudinal study of conceptual change in biology. Science Education, 81(2), 193-215.

Piaget, J. (1975). The construction of reality in the child. New York: Penguin Book.

Pratt, S. (2003). Cooperative learning strategies. The Science Teacher, 70(4), 25.

Ratnawati, E. (2016). Karakteristik Teori-Teori Belajar dalam Proses Pendidikan (Perkembangan Psikologis dan Aplikasi). Edueksos: Jurnal Pendidikan Sosial \& Ekonomi, 4(2).

Scerri, E. R. (2003). Philosophical confusion in chemical education research. Journal of Chemical Education, 80(5), 468.

Schneider, B., \& Csikszentmihalyi, M. (2000). Becoming adult: How teenagers prepare for the world of work. New York: Basic Books.

Slavin, R. E. (2006). Educational Psychologhy Theory and Practice (8th ed.). United States of America: Pearson Education.

Suparno, P. (2001). Teori perkembangan kognitif jean piaget. Kanisius.

Thompson, M., McLaughlin, C. W., \& Smith, R. G. (1995). Physical science (Wraparound). Ohio: Merrill.

Tuckman, B. W. (1999). Conducting education research. United State of America: Harcourt Brace \& Company.

Woolfolk, A. (2007). Educational psychology (10th editi). Boston: Pearson Education, Inc. 